\title{
How do regional sickness funds encourage more rational use of medicines, including the increase of generic uptake? A case study from Austria
}

\author{
Sabine Vogler, PhD; Nina Zimmermann, MA
}

\begin{abstract}
Objective: To analyse similarities and differences between activities carried out by Austrian sickness funds to encourage more rational use of medicines, including increasing generics uptake.

Methods: Semi-structured interviews with pharmacoeconomic unit staff of four regional sickness funds in Austria.

Results: Sickness funds include a variety of activities. The main target group is prescribers, who are provided information and educational materials, and whose prescription patterns are monitored. All surveyed sickness funds encourage doctors to prescribe more generics as part of an overall strategy to improved rational prescribing. Sickness funds provide patient information; however, pharmacists are not considered to be a target group. In recent years, sickness funds responsible for primary care have launched joint initiatives with hospitals, e.g. training of hospital staff, with the aim of improving pharmacotherapy at the interface between outpatient (ambulatory) and hospital care.

Discussion: All surveyed sickness funds carry out similar activities; however, the design of the individual measures differs between them as they have been adapted to meet regional differences.

Conclusion: Sickness funds have initiated a number of regional activities. The effect of these activities could be reinforced if national policies were in place to support them. Examples include generics substitution and International Nonproprietary Name prescribing, regular analysis and publication of pharmaceutical spending and consumption, and improvement of pharmacotherapy at the interface between outpatient and hospital care.
\end{abstract}

Keywords: Generics, generics uptake, medicines, monitoring, prescribing, rational use of medicines, sickness funds

\section{Introduction}

Rational use of medicines should ensure that patients receive 'medications appropriate to their clinical needs, in doses that meet their own individual requirements for an adequate period of time, and at the lowest cost to them and their community' [1]. Core policies defined by World Health Organization (WHO) to promote rational use of medicines [2] include clinical guidelines, essential medicines lists, Drug and Therapeutics Committees (DTC), training in undergraduate curricula and continuing medical education, independent information on medicines and public education, avoidance of perverse financial incentives, and sufficient and sustainable government expenditure.

All European Union (EU) and European Economic Area (EEA) countries have reimbursement lists in place, usually in the form of positive lists [3-6], and Drug and Therapeutic Committees are a standard feature in European hospitals [7]. Public education programmes have been introduced in some countries [8], such as the antibiotics campaign in France [9] and the generics campaigns in France and Portugal [10-13].

Rational use of medicines, however, continues to be a challenge in many countries, including European countries [14]. The European Surveillance of Antibiotic Consumption project showed over- and misuse of antibiotics in European countries, with wide variation in type and volume of antibiotics prescribed [15] Despite several interventions, patient adherence to medication remains poor [16-20]. Generic medicines help reduce the costs incurred by public payers $[6,21]$ and are, in accordance with the WHO Nairobi declaration [1], a way of supporting rational use of medicines. It seems, however, that generics policies are not fully exploited in some European countries [22-25]. Policies to promote generics uptake, which is defined as the increase in the use of generics compared with the originator or patent medicines within a substitutable class, include the promotion of generics substitution at all levels of the health system, and the promotion of generics acceptance by professionals, patients, and the general community [26-28].

\section{Austria's healthcare system}

Austria's healthcare system is based on a social security system with compulsory insurance. The social insurance system includes the branches of health, accident and pension insurance, and, in 2012, consisted of 22 social security institutions. Within health care, nine regional sickness funds (for the nine Austrian provinces), six occupational sickness funds, and four further institutions, e.g. social security institution for farmers, provide public health insurance services for the Austrian population [29].

The pharmaceutical sector in Austria is organized in a two-tier system, with different funding mechanisms for primary care (outpatient, general practitioners and specialists) and hospital care. In primary care, funded medicines are included in the reimbursement list (Erstattungskodex). The Austrian Main

Author for correspondence: Sabine Vogler, PhD, Head of WHO Collaborating Centre for Pharmaceutical Pricing and Reimbursement Policies, Health Economics Department, Gesundheit Österreich GmbH (Austrian Health Institute)/Geschäftsbereich ÖBIG, 6 Stubenring, AT-1010 Vienna, Austria

Submitted: 28 February 2013; Revised: 5 June 2013; Accepted: 7 June 2013; Published online first: 21 June 2013 
Association of Social Insurance Institutions (MASSI), the umbrella organization of social insurance institutions, makes decisions about the inclusion of medicines into this national positive list after a pharmacological, therapeutic and health-economic evaluation. In the case of a positive decision, the sickness funds then fund the use of the listed medicines if prescribed by outpatient doctors, i.e. those working in the community care setting $[30,31]$. Medicines in hospitals are financed out of hospital budgets and are, with some exemptions, included in the diagnosis related groups remuneration system. Social health insurance, however, co-funds inpatient medicines expenditure, as public and private non-profit hospitals for public benefit are financed by the provincial health funds, which receive funds from the federal government, the provinces, local authorities, and the social insurance institutions [32].

At the federal level, pharmaceutical policies strongly focus on pricing and reimbursement. In 2004, external price referencing for medicines to be included in the reimbursement list was introduced. It requires that the ex-factory price of these medicines cannot be higher than average prices in other EU Member States. The reimbursement system was reorganized, and a new reimbursement list ('Reimbursement Code') was launched [30, 31]. As a result of these reforms, prices can be controlled; however, pharmaceutical expenditure is still increased because of the volume component, e.g. inappropriate prescription possible over-or misuse of medicines [33].

In Austria, rational use of medicines is on the health policy agenda. For instance, the Federal Ministry of Health requested a study (published in 2008) to identify measures to control volume in Denmark compared with the situation in Austria [34]. In 2009, the multi-stakeholder working group on the rational use of medicines as part of the Pharmaceutical Committee was established as an advisory body to the Federal Ministry of Health, with the explicit aim of promoting rational use of medicines [35].

Austria has implemented a so-called 'generic price link policy' [36], i.e. it sets the prices of reimbursable generics and other 'followers' at a certain percentage lower than those of the originator, whose price subsequently also has to decrease [30]. Austria is the only country in the EU that has neither a reference price system, generics substitution nor International Nonproprietary Name (INN) prescribing in place [23]. Although a possible implementation of a reference price system and generics substitution has been discussed, a draft law to introduce such measures has not been passed [35].

Since 1999, the 'Medicine and Reason' initiative has been developing treatment recommendations for specific diseases, e.g. asthma and chronic obstructive pulmonary disease, type 2 diabetes, and rheumatoid arthritis, based on the evaluation of existing evidence. The recommendations are provided in the form of guidelines for doctors and patient leaflets. It started as a joint project between social insurance and the pharmaceutical industry. Doctor and pharmacist representatives became involved in 2003, thus ensuring broad stakeholder representation [37].
In social health insurance, responsibilities are shared between the federal entity, MASSI, and the sickness funds. MASSI decides on which medicines are selected for inclusion in the reimbursement list or remain included in the list, and at what price. This is imperative for the sickness funds. As payers, they have to cover the cost of reimbursable medicines prescribed by doctors under contract. The regional (and other) sickness funds act within the framework of decisions taken at the federal level. For instance, MASSI instigated prescribing restrictions, e.g. on statins [38], and on angiotensin receptor blocker [39], and decided to lift prescribing restrictions on generic losartan [40], with a view to enhancing the prescribing of generics; such measures could be followed up by the sickness funds.

Austrian sickness funds have also been exploring ways in which to enhance rational use of medicines, including an increased prescribing of generics. A more rational use of medicines is primarily promoted for public health reasons, but it can also contribute to savings for payers [3].

\section{Study objective}

The objective of this study was to survey measures undertaken by Austrian sickness funds to enhance more rational use of medicines, including increasing generics uptake. Particularly, we aimed to analyse the variation in types of measures and target groups, and to explore differences and similarities among the approaches selected by the sickness funds. We did not include an impact assessment of the measures. The focus of this study was on initiatives launched and carried out by the sickness funds. A comprehensive description of the national reimbursement system for medicines in Austria [30-32, 41], and initiatives undertaken by MASSI [38-40, 42, 43], have been detailed elsewhere, and are outside the scope of this study.

\section{Methods}

We conducted a survey among selected sickness funds in Austria. We chose regional sickness funds that, in general, covered people in one Austrian province. We opted for regional sickness funds because they have larger and more mixed constituencies compared with other funds, e.g. those targeting specific professions. We selected those funds that were known to have been working on enhancing rational use of medicines. In accordance with the wishes of the Austrian Federal Ministry of Health, who commissioned the survey, we focused on sickness funds in eastern, central and southern parts of Austria. The findings of the survey among the four regional sickness funds are presented in this paper. This study was exploratory and therefore did not aim for complete coverage of all sickness funds in Austria.

All selected sickness funds have a pharmacoeconomic unit that aims to encourage doctors to prescribe more rationally. Staff within these pharmacoeconomic units were the primary contacts for information and data collection. We conducted face-to-face semi-structured interviews (average duration 2-3 hours) based on an interview guide in German, the official language in Austria. On request, the interview guide was shared with the interviewees in advance. The interview was structured thematically, and included activities targeted at prescribers, patients, and pharmacists. For each of the measures, we aimed to obtain informa- 
tion on experience with the measures, supporting or limiting factors, indicators for success, accompanying materials, and evaluations.

Between February and October 2010, we conducted interviews with responsible staff in the regional sickness funds of Burgenland (Burgenländische Gebietskrankenkasse, BGKK), Carinthia (Kärntner Gebietskrankenkasse, KGKK), Lower Austria (Niederösterreichische Gebietskrankenkasse, NÖGKK) and Upper Austria (Oberösterreichische Gebietskrankenkasse, OÖGKK), and gathered additional information provided by the sickness funds.

We compiled the findings and presented them to the data providers during an internal sickness funds meeting in spring 2011. We then circulated the document to the participating sickness funds for feedback and approval. In December 2012, they were asked to check the draft paper for accuracy of the measures listed.

The data surveyed refer to the year 2010. Updated information provided during the validation phase is considered in the discussion section.

\section{Results}

The four sickness funds carried out several activities targeting their 'contract doctors', i.e. doctors in contractual relationship with them, to encourage them to prescribe more rationally. All sickness funds monitored the prescription behaviour of the doctors regularly and systematically, and used specific software tools to do this. Prescribers were provided information and feedback in different ways, e.g. written letters, personal meetings, and telephone conversations, and at different time intervals, see Table 1 .

In encouraging doctors to prescribe more rationally, sickness funds set activities to motivate doctors to prescribe more generics. All sickness funds provided information on generics in different formats, see Table 1 and Table 2. For instance, letters sent to prescribers at regular intervals contained information about the rate of generics prescribed by the individual doctor compared with the average prescribing of generics in that region, and about possible savings that could have been achieved if the doctor had prescribed more generics alternatives. Educational events organised by sickness funds, often in cooperation with regional doctors' associations, included generics as an agenda item. In training sessions for new contracted doctors, specific time slots were dedicated to pharmacoeconomic issues and prescribing of generics. Some sickness funds introduced benchmarking systems, financial incentives for contracted doctors to motivate them to prescribe generics, or both. A software system for use in doctors' offices, which was offered by the sickness funds, allowed prescribers to identify the most economic therapeutic alternative.

Communication with pharmacists was much less intensive compared with prescribers. Informal meetings were organised between pharmacist representatives and sickness funds, see Table 3. Generics promotion was one topic in these talks.
Sickness funds tended to provide information for patients. These included a health journal targeted at patients, available in print and electronic format, public information events, media campaigns, leaflets and posters in doctors' offices, and personal letters, see Table 4. A main aim of these campaigns was to raise awareness of generics among patients.

Following a recent change in legislation, sickness fund representation on the DTC in Austrian hospitals became mandatory. At the time of our survey, involvement was still relatively new. Furthermore, sickness funds launched capacitybuilding projects with the aim of improving dialogue between inpatient and outpatient care. These projects included training on rational use of medicines for junior doctors and nursing staff organised by representatives of the sickness funds at the hospital premises, see Table 5.

In addition to the activities carried out in their respective regions, sickness funds liaise with each other and with the federal entity MASSI. Pharmacoeconomic unit staff meet regularly to share and analyse data, exchange experience, and to discuss collaborations.

\section{Discussion}

The sickness funds that we surveyed have been carrying out numerous activities to encourage rational use of medicines and generics uptake. We identified 'core activities' carried out by all funds. These included various measures targeting doctors to prescribe more rationally, including the prescription of more generics wherever available and appropriate, followed by prescription monitoring.

Several of the funds interviewed highlighted the training course offered by the regional sickness funds offered to prescribers who had recently entered into contractual relationship as an example of good practice. The training course was considered to be useful because it outlined the objectives of public payers. Interviewees highlighted the importance of offering new 'contract doctors' the opportunity of becoming acquainted with staff at the sickness funds to establish trust and encourage doctors to contact sickness funds with requests or concerns. Sickness fund staff believed that these training courses contributed to increased adherence to prescribing rules. This mirrors similar experience in other countries where educational activities have enhanced the relationship between payers and prescribers, and improved prescribing quality, for example, the provision of more information and prescribing activities to increase adherence to the Wise List, a list of recommended treatments in Stockholm County in Sweden [44].

Information-technology solutions and feedback to prescribers were identified as major elements of prescription monitoring. The Austrian sickness funds apply sophisticated information-technology programmes for monitoring the prescription pattern of doctors. All sickness funds use the same data warehouse [45], but the individual sickness funds only have access to their regional data. Currently, social health insurance in Austria applies these tools for monitoring prescription behaviour. They are not, however, intended to produce aggregated data for the purpose of comparisons at regional level for policymakers, researchers and the 


\section{Table 1: Prescription monitoring activities of sickness funds}

\begin{tabular}{|c|c|c|c|c|c|}
\hline \multicolumn{2}{|c|}{ Key activities } & \multirow[b]{2}{*}{$\begin{array}{l}\text { BGKK } \\
\text { No telephone calls to } \\
\text { doctors; 1-hour visits } \\
\text { by sickness fund staff } \\
\text { with doctors who have } \\
\text { comparably high } \\
\text { expenses at their } \\
\text { premises (the talk } \\
\text { includes a 15-minute } \\
\text { discussion about } \\
\text { individual prescribing } \\
\text { behaviour) }\end{array}$} & \multirow[b]{2}{*}{\begin{tabular}{|l} 
KGKK \\
Telephone calls to \\
doctors, particularly to \\
those who could maxi- \\
mize saving potential \\
by prescribing more \\
rationally; documenta- \\
tion of the call and \\
follow-up
\end{tabular}} & \multirow[b]{2}{*}{$\begin{array}{l}\text { NÖGKK } \\
\text { Telephone calls to } \\
\text { nearly all general prac- } \\
\text { titioners and selected } \\
\text { specialists. Topics } \\
\text { include generics, costs } \\
\text { of medicines, and } \\
\text { polypharmacy; internal } \\
\text { documentation of } \\
\text { the call }\end{array}$} & \multirow[b]{2}{*}{$\begin{array}{l}\text { OÖGKK } \\
\text { Telephone calls to } \\
\text { many doctors. Topics } \\
\text { include analysis of } \\
\text { the development of } \\
\text { prescriptions, generics, } \\
\text { and polypharmacy; } \\
\text { documentation of the } \\
\text { call and follow-up }\end{array}$} \\
\hline $\begin{array}{l}\text { Talks to } \\
\text { doctors }\end{array}$ & Description & & & & \\
\hline & Frequency & At regular intervals & Annually & $\begin{array}{l}\text { Annually or more } \\
\text { frequently for new } \\
\text { doctors }\end{array}$ & Annually \\
\hline \multirow[t]{2}{*}{$\begin{array}{l}\text { Letters to } \\
\text { doctors }\end{array}$} & Description & $\begin{array}{l}\text { Written information } \\
\text { to doctors }\end{array}$ & $\begin{array}{l}\text { Each doctor receives } \\
\text { information about pre- } \\
\text { scriptions and costs }\end{array}$ & $\begin{array}{l}\text { Written information to } \\
\text { doctors }\end{array}$ & $\begin{array}{l}\text { Personalized 'service } \\
\text { letters' providing a } \\
\text { statistical overview of } \\
\text { individual prescription } \\
\text { behaviour compared } \\
\text { with the regional } \\
\text { average }\end{array}$ \\
\hline & Frequency & Monthly & Monthly & Monthly & Quarterly to all doctors \\
\hline \multirow[t]{2}{*}{$\begin{array}{l}\text { (Internal) } \\
\text { analyses }\end{array}$} & Description & \multicolumn{4}{|c|}{$\begin{array}{l}\text { Analysing the development of prescriptions and pharmaceutical expenditure as the basis for feed- } \\
\text { back to prescribers }\end{array}$} \\
\hline & Frequency & At regular intervals & At regular intervals & At regular intervals & At regular intervals \\
\hline \multirow[t]{2}{*}{$\begin{array}{l}\text { Specific } \\
\text { projects }\end{array}$} & Description & Not applicable & $\begin{array}{l}\text { Different project on } \\
\text { specific topics, e.g. } \\
\text { 'DAFLON' - personal } \\
\text { letters to doctors who } \\
\text { prescribed above the } \\
\text { regional average }\end{array}$ & $\begin{array}{l}\text { 'Doctor shopping': } \\
\text { Analysis of patient } \\
\text { medication who con- } \\
\text { sulted several doctors } \\
\text { for prescription medi- } \\
\text { cines; follow-up activi- } \\
\text { ties include letters to } \\
\text { prescribing doctors } \\
\text { and the patient }\end{array}$ & $\begin{array}{l}\text { Different projects on } \\
\text { specific topics, e.g. } \\
\text { proton pump inhibi- } \\
\text { tors; personal letters to } \\
\text { doctors who prescribed } \\
\text { above the regional } \\
\text { average }\end{array}$ \\
\hline & Frequency & Not applicable & When appropriate & $\begin{array}{l}\text { Annually and when } \\
\text { appropriate }\end{array}$ & When appropriate \\
\hline
\end{tabular}

interested public, as in other countries. Most European countries have established nation-wide monitoring systems on pharmaceutical spending and consumption, and they provide publicly accessible national (and regional) statistics, e.g. Portugal, Italy, and England, [8, 46]. In Germany, in-depth scientific analyses of prescription data are, for instance, published in the annual Prescription Monitoring Report [47]. In Denmark, the online monitoring system 'Ordiprax' offers prescribers the possibility of accessing, at any time, their prescribing data and comparing them to the average prescribing patterns of doctors of the same specialty in their region $[8,34,48]$. Some Swedish counties offer similar solutions; for instance, the county of Östergötland established an online system that also allows doctors to benchmark their prescribing behaviour against colleagues [49].

In Austria, all the sickness funds that we surveyed tailored feedback to doctors. The pharmacoeconomic units of the sickness funds send letters out to prescribers at regular intervals. These contain information about doctors' prescriptions and, in some cases, compare them to average prescribing patterns in the region. In some sickness funds, staff telephone doctors to follow up these letters. Despite these core activities of letters and discussions with doctors, our survey showed wide variance in the implementation and design of the measures between the individual sickness funds. Respondents confirmed different approaches in their communication strate- 
Table 2: Further activities of sickness funds targeting prescribers

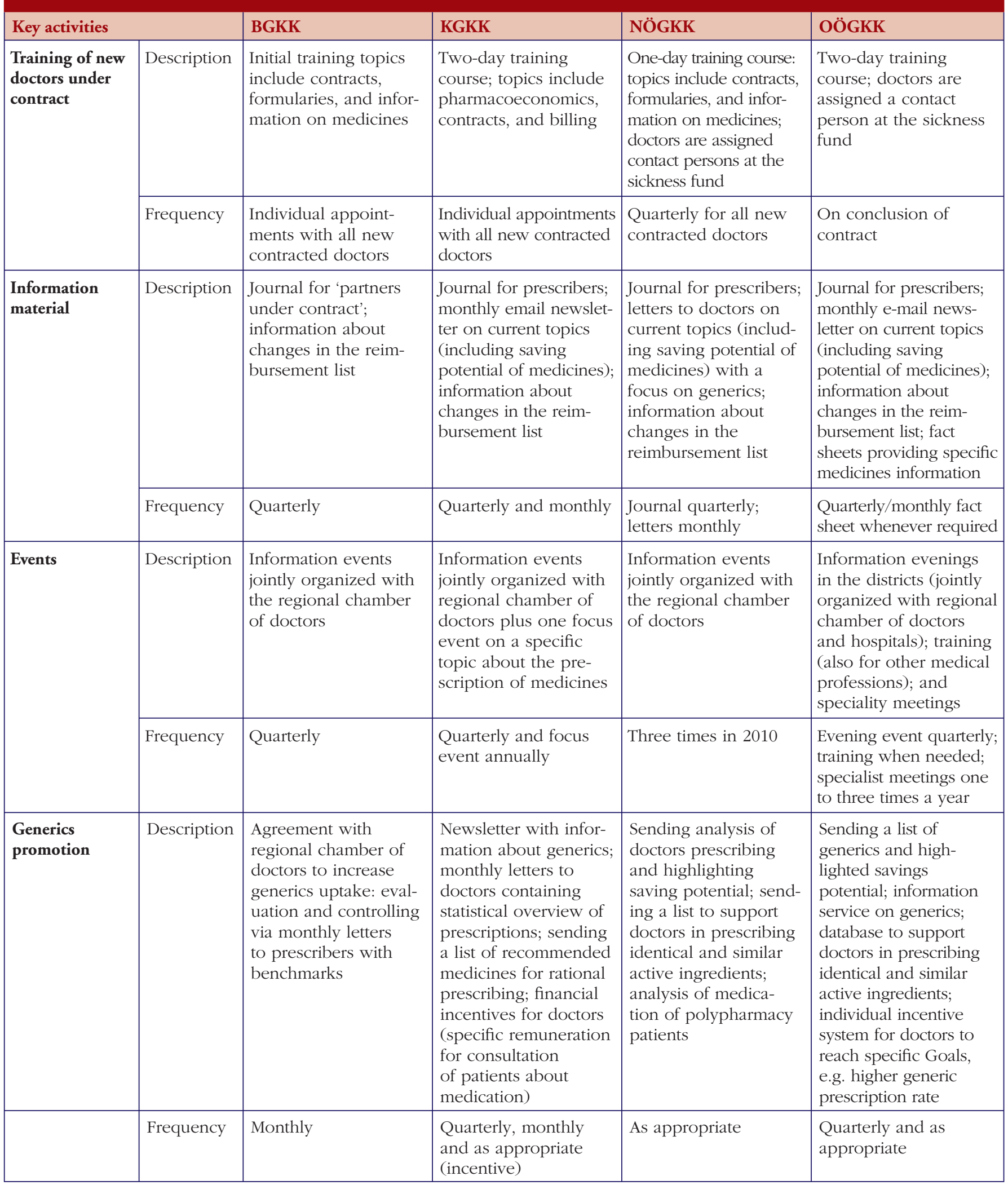


Table 2: Further activities of sickness funds targeting prescribers (Continued)

\begin{tabular}{|c|c|c|c|c|c|}
\hline \multicolumn{2}{|l|}{ Key activities } & BGKK & KGKK & NÖGKK & OÖGKK \\
\hline Pilot projects & Description & $\begin{array}{l}\text { Pilot projects with a } \\
\text { sample of doctors* }\end{array}$ & Not applicable & Not applicable & Not applicable \\
\hline
\end{tabular}

gies to prescribers, insured parties and partners, e.g. regional doctors' associations. These differences most likely stem from the different environments in which the sickness funds operate: what works well in a rural, less densely populated area is not necessarily successful in provinces with more urban centres. An example of a coordinated, yet differentiated approach is the collaboration between sickness funds on their monthly health journal sent to prescribers. Representatives of the pharmacoeconomic units form a joint editorial committee whose members discuss and define the outline of each edition. Each sickness fund then produces its own journal by considering the particulars of their constituency. These variations in strategies mirror evidence from other European countries about different regional approaches in the design of measures [50].

Another outcome of the survey was that evidence-based medicine plays an important role in the work of the pharmacoeconomic units. Staff within the funds forward economically founded arguments, e.g. possible cost savings in case of the prescription of a less expensive but equivalent generic drug, in their communication with prescribers, and they supplement these statements with the latest scientific findings. They also provide news and summaries of relevant peer-reviewed articles. As such, the sickness funds act as providers of independent medicines information that would require time and resources if doctors had to search for the information independently [51]. Supportive evidence-based data are also intended to reduce prescribers' reluctance to prescribe generics. A study in Germany, a country with a much higher generics uptake than Austria, showed that primary care doctors were still skeptical about prescribing generics [52]. Although the focus of our analysis was rather on activities related to generics promotion, some information and educational activities provided by sickness funds also focused on new medicines and polypharmacy, e.g. the initiative of the 'medicine passport' in Carinthia listing all medicines dispensed to the patient in a booklet.

Recently, some sickness funds have started to offer similar educational activities and information to private doctors.
In fact, the sickness fund of Upper Austria initiated this after the survey period. We are not aware of similar approaches in other countries. Despite the lack of evidence on the possible effect of such a measure, we consider the comprehensive strategy as a promising approach to encourage rational use of medicines.

One of the major challenges in Austria's healthcare policy is dual financing, i.e. different payers for medication in the outpatient sector (sickness funds) and in the inpatient sector (hospital owners, e.g. provinces). This creates specific incentives. In order to minimize their own costs, healthcare providers and public payers may try to transfer patients and costs between the settings. This may be the case for high-cost medicines, which pharmaceutical companies might seek to launch in the hospital sector where no price control is applied [31]. Other medicines, particularly cardiovascular medicines and other treatments for chronic diseases, are provided at low or no cost to hospitals [53-56]. Studies have confirmed how medication prescribed during the hospital stay can influence future medicines prescribed [57-59]. Therefore, the surveyed sickness funds have opened a dialogue with doctors in hospitals to discuss more rational prescribing, including the option of prescribing generics. This is a voluntary activity, as sickness funds have no mandate for hospitals and cannot hold the doctors in hospitals accountable for what they prescribe. Given the challenges on interface management, the sickness funds thereby responded to an urgent need to improve the cooperation between primary and hospital care. Findings from a project carried out by the sickness fund in the province of Burgenland showed that improved cooperation between hospital doctors, primary care doctors and sickness funds, enhanced prescribing of generics [60]. Another important initiative for medicines management at the interface is statutory participation (without voting rights) of sickness funds in every hospital via representation on the DTC. This measure had just been introduced at the time of the survey. Interview partners who had already attended DTC meetings, at the time of the survey, reported more fruitful insights into the hospital policy and activities; representation of

Table 3: Activities of sickness funds targeting pharmacists

\begin{tabular}{|l|l|l|l|l|l|}
\hline \multicolumn{2}{|l|}{ Key activities } & BGKK & KGKK & NÖGKK & OÖGKK \\
\hline Meetings & Description & $\begin{array}{l}\text { No institutionalized } \\
\text { cooperation }\end{array}$ & $\begin{array}{l}\text { Meetings with } \\
\text { regional chamber } \\
\text { of pharmacists }\end{array}$ & $\begin{array}{l}\text { No institutionalized } \\
\text { cooperation }\end{array}$ & $\begin{array}{l}\text { Meetings with } \\
\text { regional chamber } \\
\text { of pharmacists }\end{array}$ \\
\cline { 2 - 5 } & Frequency & When appropriate & Annually & As appropriate & Quarterly \\
\hline
\end{tabular}

BGKK: sickness fund of the province of Burgenland; KGKK: sickness fund of the province of Carinthia; NÖGKK: sickness fund of the province of Lower Austria; OÖGKK: sickness fund of the province of Upper Austria. 
Table 4: Activities of sickness funds targeting patients

\begin{tabular}{|c|c|c|c|c|c|}
\hline \multicolumn{2}{|l|}{ Key activities } & \multirow{2}{*}{\begin{tabular}{|l} 
BGKK \\
Health journal for \\
patients includes some \\
articles addressing \\
medicines; information \\
events
\end{tabular}} & \multirow[b]{2}{*}{$\begin{array}{l}\text { KGKK } \\
\text { Information events } \\
\text { accompanied by media } \\
\text { coverage; letters to } \\
\text { patients (includes } \\
\text { information on medi- } \\
\text { cines, generics); 'medi- } \\
\text { cines passport' for } \\
\text { patients with continu- } \\
\text { ous medication - all } \\
\text { medicines are listed in } \\
\text { this booklet; leaflets on } \\
\text { medicine information } \\
\text { available at doctors' } \\
\text { offices }\end{array}$} & \multirow[b]{2}{*}{\begin{tabular}{|l} 
NÖGKK \\
Health journal for \\
patients includes some \\
articles addressing \\
medicines; leaflets and \\
posters on medicines \\
information available \\
at doctors' offices
\end{tabular}} & \multirow[b]{2}{*}{$\begin{array}{l}\text { OÖGKK } \\
\text { Health journal for } \\
\text { patients includes some } \\
\text { articles addressing } \\
\text { medicines; leaflets } \\
\text { and posters on } \\
\text { medicine information } \\
\text { available at doctors' } \\
\text { offices; campaign } \\
\text { on medicines safety, } \\
\text { including events } \\
\text { and media work; } \\
\text { cooperation with local } \\
\text { media; cooperation } \\
\text { with patient support } \\
\text { groups }\end{array}$} \\
\hline $\begin{array}{l}\text { Information } \\
\text { on medicines } \\
\text { and generics }\end{array}$ & Description & & & & \\
\hline
\end{tabular}

BGKK: sickness fund of the province of Burgenland; KGKK: sickness fund of the province of Carinthia; NÖGKK: sickness fund of the province of Lower Austria; OÖGKK: sickness fund of the province of Upper Austria.

sickness funds on the DTCs apparently contributed to a better joint understanding.

Further measures in Austria are, however, needed to enhance interface management, e.g. joint reimbursement lists and joint DTC for outpatient and hospital care as demonstrated in Sweden [44] and Scotland [61]. This would, however, require a fundamental change in the organization and funding of the Austrian healthcare and pharmaceutical sector, which is beyond the mandate of the sickness funds.

A similar picture can be seen for all sickness funds. Most measures address doctors to encourage them to prescribe more rationally. The second important target group is the insured party who is typically addressed through information activities (journal, information events). Few measures, if any, targeted pharmacists, despite evidence showing the important role of pharmacists in enhancing more rational use of medicines in several countries [19, 24, 62-64]. The reason why pharmacists in Austria are not considered a relevant target group by sickness funds may be because pharmacists cannot play an important role in generics policies, as Austria is the only country in the EU where neither generics substitution nor INN prescribing are permitted nor is a reference price system in place [23]. Pharmacists do, however, play an important role in promoting rational use of medicines in other areas, e.g. pharmaceutical care and medication safety. Another reason that pharmacists have a lower priority than doctors is that pharmacoeconomic units in sickness funds employ few staff. They have to make choices on where to make the difference, and this will be, in economic terms, the prescribers.

Finally, it should be acknowledged that all activities carried out by sickness funds to encourage a more rational use of medicines are influenced by the underlying legal framework. The 'guidelines on economic prescription of medicines and therapeutic aids', which ask for the prescription of the least expensive equivalent medicine, can be considered a supporting factor. The lack of regulation on generics promotion regulation (no INN prescribing, no generics substitution, no reference price system [23]) is likely to be a barrier for sickness funds, because they have to motivate doctors to prescribe generics whereas, in other countries with mandatory generics substitution this would not be an issue. It has been shown that generics substitution or INN prescribing, particularly if introduced as a mandatory measure, has a positive effect on generics uptake and lowering of prices [24, 25, 36, 65-73]. Furthermore, patients in Austria are not offered incentives to ask explicitly for generics. A pilot study with a company sickness fund in Austria proved that a partial reimbursement of the prescription fee in case of a generic being dispensed led to an increased share of generic prescription and a reduction in pharmaceutical expenditure of that sickness fund [74]. Given the lack of national statutory generic promotion policies, activities provided by the sickness funds include a variety of 'voluntary' projects. This is not a new development; a decade ago, the sickness fund BGKK ran a project to increase the prescribing of generic ACE inhibitors in 2000. This resulted in considerable savings for the sickness fund [75].

BGKK was also involved in pilot projects evaluating specific diagnostic tests, as it was believed that a more detailed and reliable diagnosis could support the identification of the best treatment and also contribute to reduced pharmaceutical expenditure. A sample of 30 BGKK's contracted doctors tested the application of an immunologic rapid antigen detection test for Group A Streptococci, which helped to distinguish bacterial infection from viral infections of the upper respiratory tract. Subsequent prescribing of antibiotics was compared with the one prescription pattern of nearly all other remaining contracted general practitioners who did not have access to the test. The study 
Table 5: Activities of sickness funds targeting hospitals

\begin{tabular}{|c|c|c|c|c|c|}
\hline \multicolumn{2}{|l|}{ Key activities } & $\begin{array}{l}\text { BGKK } \\
\text { Participation in Drug } \\
\text { and Therapeutics } \\
\text { Committees (without } \\
\text { voting rights); } \\
\text { information events in } \\
\text { hospitals }\end{array}$ & $\begin{array}{l}\text { KGKK } \\
\text { Participation in Drug } \\
\text { and Therapeutics } \\
\text { Committees (without } \\
\text { voting rights); different } \\
\text { projects, e.g. meetings } \\
\text { with hospital depart- } \\
\text { ment on pain relief } \\
\text { providing ambulatory } \\
\text { care, cooperation with } \\
\text { emergency hospital on } \\
\text { reduction of proton } \\
\text { pump inhibitors, } \\
\text { assessing the effect } \\
\text { of 'shifting patients' } \\
\text { between primary } \\
\text { and secondary care } \\
\text { interface }\end{array}$ & \begin{tabular}{|l|} 
NÖGKK \\
Participation in Drug \\
and Therapeutics \\
Committees (without \\
voting rights); letters to \\
hospitals; project with \\
a hospital on improv- \\
ing pharmacotherapy \\
at the primary and \\
secondary care \\
interface
\end{tabular} & $\begin{array}{l}\text { OÖGKK } \\
\text { Participation in Drug } \\
\text { and Therapeutics } \\
\text { Committees (without } \\
\text { voting rights); meet- } \\
\text { ings with hospital } \\
\text { managers; newsletters } \\
\text { to hospitals; training } \\
\text { for junior hospital } \\
\text { doctors; training for } \\
\text { nursing staff }\end{array}$ \\
\hline
\end{tabular}

[76] showed that use of the test increased diagnostic accuracy and improved appropriate prescribing of antibiotics. With these findings and results from other studies, see Table 2, $[77,78]$, BGKK was able to contribute evidence to the scientific community. No other sickness fund provided such data.

Our study was conducted in 2010. We know that the measures listed continue to be undertaken and have even expanded. Cooperation between sickness funds and hospitals has increased because of sickness fund representation on the DTC and some further projects. For instance, in Upper Austria, patient discharge letters indicate the name of the active ingredient instead of the specific brand name, and hospitals procure defined generics that are likely to be used in outpatient treatment.

We acknowledge possible shortcomings in the findings owing to the selected methodology of qualitative interviews. Some measures, however relevant, might not have been listed by a sickness fund. We are confident that we have covered all major activities, as the measures were compiled and shared with the data providers for feedback. It allowed us to verify the accuracy of the information.

Even if the survey does not comprehensively cover all Austrian sickness funds, we believe that the survey is of value because it provides information about the strategies used by sickness funds to improve rational use of medicines. It may, therefore, serve as a starting point for reflections on how to continue enhancing rational use and generics promotion in future.

\section{Conclusion}

This survey showed that numerous activities are being implemented by Austrian sickness funds to encourage more rational use of medicines. Most initiatives target contracted doctors to motivate them to prescribe rationally. In particular, sickness funds encourage doctors to prescribe more generics. Sickness funds are required to apply this strategy because neither INN prescribing nor generics substitution is in place in Austria to support generics uptake.

We suggest stronger involvement of pharmacists. Pharmacists could play a vital role in generics promotion, particularly by contributing to an improved image of generics. Although more measures to encourage rational use of medicines are welcome, we acknowledge limited staff resources within the sickness funds may make this difficult. The findings suggest that the pharmacoeconomic units provide activities over and above their specified remits.

A key challenge in the Austrian healthcare system is cooperation between the outpatient and hospital sectors which is disincentivized by a dual financing scheme. Sickness funds responsible for primary care are now targeting hospitals with their information and educational activities. These are important initiatives, but further policies would be required at national level, e.g. a joint DTC, to improve pharmacotherapy at the interface between primary care and hospitals.

At the national level, a publication of pharmaceutical spending and consumption monitoring is currently lacking. It is recommended exploring ways in which to implement a nationwide monitoring system.

The sickness funds apply a range of tools to enhance more rational use of medicines, including improving generics 
uptake. No evaluation of the effect of these policies has yet been published. Further research is required to analyse the effectiveness of the measures.

\section{Acknowledgements}

We are very grateful to the members of the four sickness funds presented: DI Berthold Reichardt (Burgenländische Gebietskrankenkasse); Dr Margot Reiter, Dr Ursula Riess, Dr Bernadette Mörtl-Kessler (Kärntner Gebietskrankenkasse); Herbert Feichter, Dr Michaela Stitz, Dr Jana Fischer, Msc (Niederösterreichische Gebietskrankenkasse); and Dr Anna Labek, MPH, Mag Gerhard Arzt (Oberösterreichische Gebietskrankenkasse).

They were available for face-to-face interviews, provided a wealth of information and materials, and checked the accuracy of the measures and activities listed. This paper would never have been possible without their contributions.

Furthermore, we would like to thank all members of the group Argumentationsgruppe Heilmittel, in which the interview partners of the surveyed sickness funds were represented, for their interest in the study and for encouraging us to produce this manuscript.

We also thank our colleague Ms Bettina Schmickl who supported this study by participating in some of the interviews and reporting them.

Finally, our thanks go to Dr Wolfgang Ecker of the Austrian Federal Ministry of Health who commissioned Gesundheit Österreich $\mathrm{GmbH}$ to conduct this study.

\section{For patients}

It is important that public payers take action to meet the policy goals of sustainable funding and encourage a more rational use of medicines, including prescribing of generic medicines. In this paper, we review the activities carried out by sickness funds in Austria and provide evidence that successful practices can be implemented at regional level. A possible mix of policies and activities could be undertaken to contribute to more rational use of medicines. Although more rational use of medicines may have some cost-containment implications for payers, it benefits, first and foremost, patients by increasing patient safety and adherence.

\section{Sources of support}

The survey with the sickness funds was funded by the Austrian Federal Ministry of Health. No specific funding was provided for the writing of the article.

\section{Competing interests: None.}

Provenance and peer review: Not commissioned; externally peer reviewed.

\section{Co-author}

Nina Zimmermann, MA

WHO Collaborating Centre for Pharmaceutical Pricing and Reimbursement Policies, Health Economics Department, Gesundheit Österreich $\mathrm{GmbH}$ (Austrian Health Institute)/Geschäftsbereich ÖBIG, 6 Stubenring, AT-1010 Vienna, Austria

\section{References}

1. World Health Organization. The rational use of drugs. Report of the conference of experts, Nairobi, 25-29 November 1985. 1987 [cited 2013 Jun 5]. Available from: http://apps.who.int/medicinedocs/documents/s17054e/s17054e.pdf

2. World Health Organization. Promoting rational use of medicines: core components. WHO Policy Perspectives on Medicines. 2002;5:1-6.

3. Vogler S, Habl C, Leopold C, Rosian-Schikuta I. PPRI Report. Vienna: Gesundheit Österreich GmbH/Geschäftsbereich ÖBIG; 2008.

4. Vogler S, Espin J, Habl C. Pharmaceutical Pricing and Reimbursement Information (PPRI) - New PPRI analysis including Spain. Pharmaceuticals Policy and Law. 2009;11(3):213-34.

5. Vogler S, Habl C, Bogut M, Voncina L. Comparing pharmaceutical pricing and reimbursement policies in Croatia to the European Union Member States. Croat Med J. 2011;52(2):183-197.

6. Carone G, Schwierz C, Xavier A. Cost-containment policies in public pharmaceutical spending in the EU. Brussels: European Commission, Directorate-General for Economics and Financial Afairs, 2012 [cited 2013 Jun 5]. Available from: http://ec.europa.eu/economy_finance/publications/ economic_paper/2012/pdf/ecp_461_en.pdf

7. Vogler S, Habl C, Leopold C, Mazag J, Morak S, Zimmermann N. PHIS Hospital Pharma Report. Vienna: Pharmaceutical Health Information System; Gesundheit Österreich GmbH / Geschäftsbereich ÖBIG; 2010.

8. Vogler S, Schmickl B. Rationale Arzneimitteltherapie in Europa. Vienna: Gesundheit Österreich GmbH; 2010.

9. Sabuncu E, David J, Bernède-Bauduin C, Pépin S, Leroy M, Boëlle P-Y, et al. Significant reduction of antibiotic use in the community after a nationwide campaign in France, 2002-2007. PLoS medicine. 2009;6(6):e1000084.

10. Godman B, Bennie M, Baumgärtel C, Sović-Brkičić L, Burkhardt T, Fürst J, et al. Essential to increase the use of generics in Europe to maintain comprehensive health care? Farmeconomia Health economics and therapeutic pathways. 2012;13(3S):5-20.

11. Sermet C, Andrieu V, Godman B, Van Ganse E, Haycox A, Reynier JP. Ongoing pharmaceutical reforms in France: implications for key stakeholder groups. Appl Health Econ Health Policy. 2010;8(1):7-24.

12. Lopes S, Marty C, Berdai D. PHIS Pharma Profile France. Vienna: Gesundheit Österreich GmbH / Geschäftsbereich ÖBIG; 2011.

13. Habl C, Vogler S, Leopold C, Schmickl B, Fröschl B. Referenzpreissysteme in Europa. Analyse und Umsetzungsvoraussetzungen für Österreich.Vienna, 2008.

14. Holloway K, Van Dijk L. Rational use of medicines. In: World Health Organization (WHO), Editors. The World Medicines Situation 2011. Geneva; 2011.

15. Ferech M, Coenen S, Malhotra-Kumar S, Dvorakova K, Hendrickx E, Suetens C, et al. European Surveillance of Antimicrobial Consumption (ESAC): outpatient antibiotic use in Europe. J Antimicrob Chemother. 2006;58(2):401-7.

16. Haynes RB, Ackloo E, Sahota N, McDonald HP, Yao X. Interventions for enhancing medication adherence. Cochrane Database Syst Rev. 2008;(2):CD000011.

17. Hughes DA, Bagust A, Haycox A, Walley T. The impact of non-compliance on the cost-effectiveness of pharmaceuticals: a review of the literature. Health Econ. 2001;10(7):601-15.

18. van Dulmen S, Sluijs E, van Dijk L, de Ridder D, Heerdink R, Bensing J. Patient adherence to medical treatment: a review of reviews. BMC Health Serv Res. 2007;7(1):55.

19. Van Wijk BL, Klungel OH, Heerdink ER, de Boer A. Effectiveness of Interventions by Community Pharmacists to Improve Patient Adherence to chronic medication: a systematic review. Ann Pharmacother. 2005;39(2):319-28.

20. Vermeire E, Hearnshaw H, Van Royen P, Denekens J. Patient adherence to treatment: three decades of research. A comprehensive review. Journal of Clinical Pharmacy and Therapeutics. 2001;26(5):331-42.

21. Godman B, Wettermark B, Bishop I, Burkhardt T, Fürst J, Garuoliene K. European payer initiatives to reduce prescribing costs through use of generics. 
Generics and Biosimilars Initiative Journal (GaBI Journal). 2012;1(1):22-7. doi:10.5639/gabij.2012.0101.007

22. Vogler S, Habl C, Leopold C, Rosian-Schikuta I. PPRI Conference 2007. Agenda. PPRI Conference; 29.05.2012; Vienna: PPRI (Pharmaceutical Pricing and Reimbursement Information); 2007.

23. Vogler $\mathrm{S}$. The impact of pharmaceutical pricing and reimbursement policies on generics uptake: implementation of policy options on generics in 29 European countries-an overview. Generics and Biosimilars Initiative (GaBI) Journal. 2012;1(2):93-100. doi:10.5639/gabij.2012.0102.020

24. Dylst P, Vulto A, Simoens S. Demand-side policies to encourage the use of generic medicines: an overview. Expert Rev Pharmacoecon Outcomes Res. 2013;13(1):59-72.

25. Vitry A, Martin A, MPharmS BG, Sermet C, Herholz H, Bishop I, et al. Payers endorse generics to enhance prescribing efficiency: impact and future implications, a case history approach. Generics and Biosimilars Initiative Journal (GaBI Journal). 2012;1(2):69-83. doi:10.5639/gabij.2012.0102.017

26. World Health Organization. Technical Brief Series - Brief No 1: Improving access to essential medicines and creating efficiencies by encouraging the uptake of generic medicines. [cited 2013 Jun 5]. Available from: http://www. who.int/healthsystems/topics/financing/healthreport/GenericsTBNo1.pdf

27. Cameron A, Laing R. Cost savings of switching private sector consumption from originator brand medicines to generic equivalents. World Health Report, Background Paper, 35. 2010 [cited 2013 Jun 5]. Available from: http://www.who.int/ healthsystems/topics/financing/healthreport/35MedicineCostSavings.pdf

28. World Health Organization, Health Action International (HAI). Measuring medicine prices, availability, affordability and price components. 2nd edition. Geneva, 2008

29. Habl C, Bachner F, Klinser D, Ladurner J. The Austrian Health Care System. Key Facts. Vienna: Austrian Federal Ministry of Health; 2010.

30. Leopold C, Habl C, Vogler S, Morak S. PPRI Pharma Profile Austria. Vienna: Gesundheit Österreich GmbH/Österreichisches Bundesinstitut für Gesundheitswesen (GÖG/ÖBIG), commissioned by the European Commission, DG Public Health and Consumers and the Austrian Federal Ministry of Health; 2008

31. Godman B, Bucsics A, Burkhardt T, Haycox A, Seyfried H, Wieninger P. Insight into recent reforms and initiatives in Austria: implications for key stakeholders. Expert Rev Pharmacoecon Outcomes Res. 2008;8(4):357-71

32. Zimmermann N, Vogler S. PHIS Hospital Pharma Report Austria. Vienna: Gesundheit Österreich GmbH/Geschäftsbereich ÖBIG; 2009.

33. Czypionka T, Riedel M, Röhrling G, Mayer S, Rasinger T. Mengenkontrolle im Arzneimittelbereich: internationale Evidenz für Österreich. Health System Watch. 2010(3):1-16. German

34. Leopold C, Habl C, Vogler S, Rosian-Schikuta I. Steuerung des Arzneimittelverbrauchs am Beispiel Dänemark. Vienna: Gesundheit Österreich GmbH (Austrian Health Institute); 2008.

35. Hlava A, Bednar W, Birner A, Bronneberg G, Fülöp G, Grabner I, et al. Gesundheitsbericht an den Nationalrat 2009: Berichtszeitraum 2005-2007 [Health Report to Parliament 2009. Reporting period 2005-2007; report in German]. Vienna: Federal Ministry of Health and Gesundheit Österreich GmbH (Austrian Health Institute); 2009.

36. Vogler S. How large are the differences between originator and generic prices? Analysis of five molecules in 16 European countries. Farmeconomia Health economics and therapeutic pathways. 2012;13(Suppl 3):29-41.

37. Initiative Arznei \& Vernunft. Vernünftiger Umgang mit Medikamenten. [cited 2013 Jun 5]. Available from: http://www.arzneiundvernunft.info/

38. Godman B, Burkhardt T, Bucsics A, Wettermark B, Wieninger P. Impact of recent reforms in Austria on utilization and expenditure of PPIs and lipid-lowering drugs: implications for the future. Expert Rev Pharmacoecon Outcomes Res. 2009;9(5):475-84

39. Vončina L, Strizrep T, Godman B, Bennie M, Bishop I, Campbell S, et al. Influence of demand-side measures to enhance renin-angiotensin prescribing efficiency in Europe: implications for the future. Expert Rev Pharmacoecon Outcomes Res. 2011;11(4):469-79.

40. Bucsics A, Godman B, Burkhardt T, Schmitzer M, Malmström RE. Influence of lifting prescribing restrictions for losartan on subsequent sartan utilization patterns in Austria: implications for other countries. Expert Rev Pharmacoecon Outcomes Res. 2012;12(6):809-19.

41. Zimmermann N, Vogler S. PPRI/PHIS Pharma Profile Austria (draft, unpublished). Pharmaceutical Pricing and Reimbursement Information (PPRI)/Pharmaceutical Health Information System (PHIS). Vienna: Gesundheit

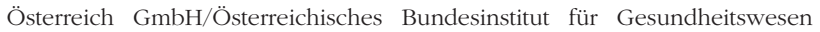
(GÖG/ÖBIG); 2012

42. Godman B, Bucsics A, Burkhardt T, Schmitzer M, Wettermark B, Wieninger P. Initiatives to enhance renin-angiotensin prescribing efficiency in Austria: impact and implications for other countries. Expert Rev Pharmacoecon Outcomes Res. 2010;10(2):199-207.

43. Malmström R, Godman B, Diogene E, Baumgaertel C, Bennie M, Bishop I, et al. Dabigatran - a case history demonstrating the need for comprehensive approaches to optimize the use of new drugs. Front Pharmacol. 2013;4:39.

44. Gustafsson LL, Wettermark B, Godman B, Andersén-Karlsson E, Bergman U, Hasselström J, et al. The 'wise list'- A comprehensive concept to select, communicate and achieve adherence to recommendations of essential drugs in ambulatory care in Stockholm. Basic Clin Pharmacol Toxicol. 2011;108(4):224-33.

45. Ganjeizadeh-Rouhani A. Business Intelligence im Gesundheitswesen. Soziale Sicherheit. 2010 (July/August):366-71.

46. Kullman D. Vienna: Pharmaceutical Health Information System (PHIS); 2011. Pharma Profile United Kingdom.

47. Schwabe U, Paffrath D. Arzneiverordnungs-Report 2012: Aktuelle Daten, Kosten, Trends und Kommentare. Springer; 2012.

48. Thomsen E, Er S, Rasmussen PF. PPRI Pharma Profile Denmark. Vienna: Gesundheit Österreich GmbH/Österreichisches Bundesinstitut für Gesundheitswesen (GÖG/ÖBIG); 2008.

49. Godman B, Wettermark B, Hoffmann M, Andersson K, Haycox A, Gustafsson LL. Multifaceted national and regional drug reforms and initiatives in ambulatory care in Sweden: global relevance. Expert Rev Pharmacoecon Outcomes Res. 2009;9(1):65-83.

50. Saltman RB, Busse R, Figueras J. Social health insurance systems in western Europe. Maldenhead, New York; 2004.

51. Schaaber J, Kochen MM, Müller-Oerlinghausen B, Niebling W. Warum unabhängige Arzneimittelzeitschriften und Fortbildungsveranstaltungen wichtig sind. In: Lieb K, Klemperer D, Ludwig W-D, Eds. Interessenkonflikte in der Medizin: Springer Berlin Heidelberg; 2011. p. 237-52.

52. Simmenroth-Nayda A, Hummers-Pradier E, Ledig T, Jansen R, Niebling W, Bjerre LM, et al. Prescription of generic drugs in general practice. Results of a survey of general practitioners. Med Klin. 2006;101(9):705-10. German.

53. Vogler S, Habl C, Leopold C, Mazag J, Morak S, Zimmermann N. PHIS Hospital Pharma Report. Vienna: Commissioned by the European Commission, Executive Agency for Health and Consumers (EAHC) and the Austrian Federal Ministry of Health (BMG); 2010.

54. Langebner T. Managing drug costs in Austria. Eur J Hosp Pharm Prac. 2007;13(5):79

55. de Vries CS, van Diepen NM, Tromp TF, de Jong-van den Berg LT. Auditing GPs' prescribing habits: cardiovascular prescribing frequently continues medication initiated by specialists. Eur J Clin Pharmacol. 1996;50(5):349-52.

56. Vogler S, Zimmermann N, Leopold C, Habl C, Mazag J. Discounts and Rebates Granted for Medicines for Hospital Use in Five European Countries. The Open Pharmacoeconomics \& Health Economics Journal. 2013(5). Epub ahead of print.

57. Gallini A, Legal R, Taboulet F. The influence of drug use in university hospitals on the pharmaceutical consumption in their surrounding communities. Br J Clin Pharmacol. 2013 Apr;75(4):1142-8.

58. Feely J, Chan R, McManus J, O'Shea B. The influence of hospital-based prescribers 
on prescribing in general practice. Pharmacoeconomics. 1999;16(2):175-81.

59. Fahey T, Sinclair H. Hospital initiated prescribing in the General Medical Services scheme. Ir Med J. 1993;86(4):122-4.

60. Wolzt M, Ohrenberger G, Reichardt B. Cost reduction with project based prescription of generic ACE inhibitors. Wien Klin Wochenschr 2003;115(1-2):23-8. German.

61. Herms S, Rutledge P. The Lothian Joint Formulary: overcoming the barriers to formulary success. Pharmacy in Practice. 2002;12(6):279-85.

62. Vogler S, Arts D, Habl C. Community Pharmacy in Europe. Lessons from deregulation - case studies. Vienna: Österreichisches Bundesinstitut für Gesundheitswesen (ÖBIG); 2006.

63. Clifford S, Barber N, Elliott R, Hartley E, Horne R. Patient-centred advice is effective in improving adherence to medicines. Pharm World Sci. 2006; 28(3): 165-70.

64. Nkansah N, Mostovetsky O, Yu C, Chheng T, Beney J, Bond C, et al. Effect of outpatient pharmacists' non-dispensing roles on patient outcomes and prescribing patterns. Cochrane Database of Syst Rev. 2010;(7).

65. Redman T, Köping Höggärd M. PPRI Pharma Profile Sweden.

66. Bennie M, Godman B, Bishop I, Campbell S. Multiple initiatives continue to enhance the prescribing efficiency for the proton pump inhibitors and statins in Scotland. Expert Rev Pharmacoecon Outcomes Res. 2012;12(1):125-30.

67. Godman B, Shrank W, Andersen M, Berg C, Bishop I, Burkhardt T, et al. Policies to enhance prescribing efficiency in Europe: findings and future implications. Front pharmacol. 2010;1:141.

68. Duerden MG, Hughes DA. Generic and therapeutic substitutions in the UK: are they a good thing? Br J Clin Pharmacol. 2010;70(3):335-41.

69. Simoens S. The Portuguese generic medicines market: a policy analysis. Pharmacy Practice. 2009;7(2):74-80.
70. Godman B, Shrank W, Wattermark B, Andersen M, Bishop I, Gustafsson LL. Use of generics - a critical cost containment measure for all healthcare professionals in Europe? Pharmaceuticals. 2010;3(8):2470-94.

71. Vogler S, Zimmermann N. The potential of generics policies: more room for exploitation-PPRI Conference Report. Generics and Biosimilars Initiative Journal (GaBI Journal). 2012;1(3-4):146-9. doi:10.5639/gabij. 2012.0103-4.030

72. Aalto-Setälä V. The impact of generic substitution on price competition in Finland. Eur J Health Econ. 2008;9(2):185-91.

73. Garuoliene K, Godman B, Gulbinovič J, Wettermark B, Haycox A. European countries with small populations can obtain low prices for drugs: Lithuania as a case history. Expert Rev Pharmacoecon Outcomes Res. 2011;11(3):343-9.

74. Gouya G, Reichardt B, Bidner A, Weissenfels R, Wolzt M. Partial reimbursement of prescription charges for generic drugs reduces costs for both health insurances and patients [Article in German]. Wien Klin Wochenschr. 2008; 120(3-4):89-95. German.

75. Rosian I, Vogler S. Generika Modell Burgenland. Wien: Österreichisches Bundesinstitut für Gesundheitswesen; 2001. German.

76. Reichardt B, Pichlhöfer O, Zehetmayer S, Maier M. Current diagnosis of acute pharyngitis. [Article in German]. Wien Med Wochenschr. 2009; 159(7-8):202-6. German.

77. Hoffmann K, Reichardt B, Zehetmayer S, Maier M. Evaluation of the implementation of a rapid streptococcal antigen test in a routine primary health care setting. Wien Klin Wochenschr. 2012;124(17-18):633-8.

78. Hoffmann K, Leifheit AK, Reichardt B, Maier M. The antibiotic prescription and redemption gap and opportunistic CRP point-of-care testing. A cross-sectional study in primary health care from Eastern Austria. Wien Klin Wochenschr. 2013:1-6.

DOI: 10.5639 /gabij.2013.0202.027

Copyright @ 2013 Pro Pharma Communications International 